\title{
Antitumoral, mutagenic and (anti)estrogenic activities of tingenone and pristimerin
}

\section{Juliana P. M. Gomes, ${ }^{1}$ Cássia R. P. Cardoso, ${ }^{1}$ Eliana A. Varanda, ${ }^{*}, 1$ José-Manuel Molina, ${ }^{2}$ Mariana F. Fernandez, ${ }^{2}$ Nicolás Olea, ${ }^{2}$ Iracilda Z. Carlos, ${ }^{2}$ Wagner Vilegas ${ }^{3}$}

${ }^{l}$ Faculdade de Ciências Farmacêuticas, Universidade Estadual Paulista "Júlio de Mesquita Filho, Campus Araraquara, Brazil,

${ }^{2}$ University of Granada, Cíber en Epidemiología y Salud Pública, Spain,

${ }^{3}$ Instituto de Química, Universidade Estadual Paulista "Júlio de Mesquita Filho, Campus Araraquara, Brazil.

\begin{abstract}
Cancer constitutes the second main mortality cause in the world, after cardiovascular diseases. In spite of the progresses in the chemotherapeutics treatments, many patients fail chemotherapy, mainly because of side effects or multidrugs resistance, proving the need and importance of the research for new molecules with anticancer activity, more effective and with smaller adverse effects. Various compounds derived from plant secondary metabolites are commonly used in the chemotherapy against cancer and the natural products play an important role in the research for new molecules. Among several molecules of natural origin evaluated by MTT assay in murine tumor cell lines [breast (LM3) and lung (LP07)] the quinonamethide triterpenes tingenone and pristimerin showed marked cytotoxic activity presenting IC50 around 2 and $5 \mu \mathrm{M}$ respectively. The structure-activity relationship suggests that rings $\mathrm{A}$ and $\mathrm{B}$ containing an $\alpha, \beta$-unsaturated carbonyl group are essential for the observed cytotoxic activity. The interaction between these positions and acetylcisteyne residues suggests a probable mechanism of action. The in vitro mutagenic activity was also evaluated by the Salmonella microsome assay (Ames test) for pristimerin and tingenone with and without metabolic activation (S9) in the strains TA98, TA97a, TA100 and TA102, none of which showed mutagenic potential in any strains. Estrogenic and anti-estrogenic activities were also studied by the e-screen assay in MCF-7 cells with negative results. The present data point to the importance of pristimerin and tingenone as representative of an emerging class of potential anticancer chemicals.
\end{abstract}

Revista Brasileira de Farmacognosia Brazilian Journal of Pharmacognosy 21(6): 963-971, Nov./Dec. 2011

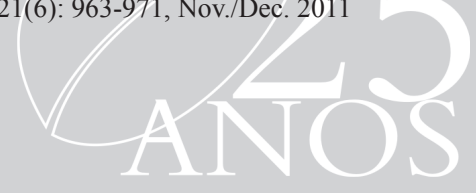

\section{Article}

Received 10 Nov 2010

Accepted 11 Feb 2011

Available online 26 Aug 2011

Keywords:

(anti)estrogenic activity cytotoxic activity mutagenic activity plumericin pristimerin tingenone

ISSN 0102-695X http://dx.doi.org/10.1590/S0102 $695 \times 201100500015$

\section{Introduction}

Therapeutic and special dietary use of plants is a worldwide habit. Herbal remedies are believed by the general public to be safe, cause less side-effects and less likely to cause dependency (Linchy and Berry, 2007). Today, drugs derived from plants are investigated for the possible presence of mutagenic and/ or carcinogenic substances, as well as other biological activities. Moreover, there is an intense discussion in the scientific and even more so in the public community about the potential (benefits or detrimental) effects of plant-derived compounds that may affect the endocrine system, especially estrogen signaling pathways (Messina and Wood, 2008). Dimitrakakis et al. (2004) reported adverse events included the development of male breast cancer after prolonged consumption of a phytoestrogen.
Various compounds derived from plant secondary metabolites are commonly used in cancer treatment, such as paclitaxel, campothecin and tenoposide. Chemotherapy has been improved over the past years, but to date, many patients fail chemotherapy, mainly because of side effects or multi-drugs resistance. Natural products continue to perform an essential role in the research for new anticancer molecules (Costa et al., 2008).

Pristimerin and tingenone, naturally occurring quinonemethide triterpenoid compounds, are traditional medicines derived from the Celastraceae and Hippocrateaceae families and have long been used as anti-inflammatory, antioxidant, antimalarial, and insecticidal agents (Brinker et al., 2007; Gao et al., 2007). It has been reported that they have promising clinical potential as both a therapeutic and chemopreventive agent for cancer (Salminen et al., 
2008).

Since many herbal medicines have undergone little or no research, often there is little objective information about the potential risks and benefits of their use. Despite the popular notion of herbs as safe, a variety of adverse events associated with their use alone or in combination with conventional anticancer therapy has been reported including the occurrence of severe bone marrow depression. Oncologists and medical practitioners should be aware of the adverse effects associated with these herbs, and be sure to obtain a thorough history of the use of such compounds from their patients. In this context, the assays of cytotoxicity associated with mutagenic and estrogenic activities are important.

Salmonella typhimurium/microsome assay (Ames test) is a widely accepted short-term bacterial assay for identifying substances that can produce genetic damage that leads to gene mutations. The Ames test is used world-wide as an initial screen to determine the mutagenic potential of new chemicals and drugs (Mortelmans \& Zeiger, 2000).

The e-screen is a quantitative test that compares the growth among cultures of MCF-7 cells treated with $17-\beta$-estradiol and cultures treated with different concentrations of the substance suspects of presenting estrogenic activity (Soto et al., 1995).The phytoestrogens can exert estrogenic or antiestrogenic effects depending on the dose, when they adhere to the hormonal receptors (Roberts, 2010; Xin, 2010). The e-screen assay is based in the concept that human cells of breast cancer MCF-7 proliferate in the presence of chemical substances that activate estrogenic receptors direct or indirectly (Soto et al., 1995; Spink et al., 2006).

The present study was carried out to evaluate the in vitro cytotoxicity from natural products such as pristimerin (1), tingenone (2), plumericin, chromeno (methyl 2,2 -dimethyl-4-oxo-3,4,6,8a-tetrahydro2H-chromene-6-carboxilate), bauerenyl acetate, $p$-coumaric acid, chlorogenic acid and scandenin in the cell lines of adenocarcinoma murine of breast (LM3) and lung (LP07), seeking for molecules with promising anticancer activity. Pristimerin and tingenone was also evaluated in assays with Salmonella typhimurium using the strains TA100, TA102, TA98 and TA97a with and without metabolic activation (S9) and their estrogenic and antiestrogenic activities in MCF-7 cells. The study attempted to identify possible correlations between molecular structure of these natural products and anticancer activity.

\section{Materials and Methods}

Natural products
Pristimerin (1), tingenone (2), plumericin, chromeno (methyl 2,2 -dimethyl-4-oxo-3,4,6,8atetrahydro-2H-chromene-6-carboxilate), bauerenyl acetate, $p$-coumaric acid, chlorogenic acid and scandenin were provided by Dr. Wagner Vilegas, São Paulo State University (Araraquara-SP, Brazil). These compounds were isolated from several plants and identified by proper techniques. Their purity was checked by HPLC and is higher than $98 \%$. Pacitaxel was purchased from Sigma, $>99 \%$ pure.

Assays

Cytotoxicity against tumor cell lines (MTT assay):

The cytotoxic potential of the natural products was evaluated by the MTT assay (Mosmamm, 1983) against two adenocarcinomas murines of breast (LM3) and lung (LP07) cell lines kindly provided by Dr. Lucas L. Colombo (Angel H. Roffo Oncology Institute, Buenos Aires, Argentina). Both cell lines were maintained in MEM medium (Gibco) supplemented with 10\% fetal bovine serum (Gibco) and $0.1 \%$ gentamicin sulfate (80 $\mathrm{mg} / \mathrm{mL}$ - Mantecorp), at $37{ }^{\circ} \mathrm{C}$ and $5 \% \mathrm{CO}_{2}$. Tumor cell growth was quantified by the capability of living cells to reduce the yellow dye 3-(4,5-dimethyl2-thiazolyl)-2,5-diphenyl-2H-tetrazolium bromide (MTT - Sigma Co.) to a purple formazam product. Cells were previously plated in 96-well plates (200 $\mu \mathrm{L}$ of $5 \times 10^{4}$ cell/mL solution in each well) for $24 \mathrm{~h}$, when the supernatant was replacement for $200 \mu \mathrm{L} /$ well solution of the natural products $(0.24-500 \mu \mathrm{g} / \mathrm{mL})$ with maximum $0.5 \%$ DMSO. After $24 \mathrm{~h}$, the supernatant was replaced by fresh medium containing MTT $(1 \mathrm{mg} / \mathrm{mL})$. Three hours later the supernatant was wasted and added $100 \mu \mathrm{L} /$ well of isopropyl alcohol for dissolving the MTT formazan product. The absorbance was promptly measured at $540 \mathrm{~nm}$ and reference filter at $620 \mathrm{~nm}$ (Multiskan ascent, Labsystem). Paclitaxel was used as positive control. Each concentration was analyzed in triplicate, and two independent experiments were realized.

Pristimerin (1) and tingenone (2) are also assayed by the same protocol in presence of $\mathrm{N}$-acetylcisteyne (1 $\mu \mathrm{moL} / \mathrm{mL})$. The source of $N$-acetylcisteyne was the medicine Fluimucil (200 mg - effervescent granulateZambon).

\section{Spectrophotometric analysis}

The absorbance from each solutions of pristimerin and tingenone $(0.02 \mathrm{~g} / \mathrm{mL})$ in methanol (HPLC/spectro - Tedia), were measured at $\lambda=200-700$ $\mathrm{nm}$ by DR/4000U Spectrophotometer (Hach). The 
same procedure was repeated for the mixture of each triterpene with $\mathrm{N}$-acetylcisteyne $(1: 5 \mathrm{~mol})$ in milli-Q water (Direct-QTM -Millipore) after $30 \mathrm{~min}$ in ambient temperature.

\section{Mutagenicity assay (Ames test)}

The Salmonella mutagenicity assay was performed with S. typhimurium strains TA97a, TA98, TA100 and TA102, pre-incubated for 20-30 min with and without metabolic activation (Maron \& Ames, 1983). The S9-mix (mixture from several liver enzymes and cofactors) was freshly prepared before each test using Aroclor-1254-induced rat liver fraction purchased (lyophilized) from Moltox (Molecular Toxicology Inc.). S. typhimurium strains were kindly provided by Dr. B. Ames, University of California (Berkeley, CA, USA).

Selected concentrations of pristimerin and tingenone were used; dissolved in DMSO (Sigma Chemical Co. - St. Louis, MO, USA). The concentrations were chosen in a preliminary test on the basis of bacterial toxicity. In all subsequent assays, the upper limit of the dose range tested was either the highest non-toxic dose or the lowest toxic dose determined in this preliminary assay. Toxicity was apparent either as a reduction in the number of his + revertants, or as an alteration in the auxotrophic background lawn. The various concentrations of samples were added to $500 \mu \mathrm{L}$ of buffer ( $\mathrm{pH} \mathrm{7.4)} \mathrm{and} 100 \mu \mathrm{L}$ of bacterial culture and then incubated at $37{ }^{\circ} \mathrm{C}$ for $20-30 \mathrm{~min}$. After this time, $2 \mathrm{~mL}$ of top agar were added to the mixture and poured on to a plate containing minimal agar. The plates were incubated at $37^{\circ} \mathrm{C}$ for $48 \mathrm{~h}$ and his + revertant colonies were manually counted. The influence of metabolic activation was tested by adding $500 \mu \mathrm{L}$ of S9 mixture $(4 \%)$ to the pre-incubation mixture. All experiments were analyzed in triplicate.

The standard mutagens used as positive controls in experiments without S9-mix were 4-nitro$O$-phenylenediamine $(10 \mu \mathrm{g} /$ plate $)$ for TA98 and TA97a, sodium azide $(2.5 \mu \mathrm{g} /$ plate $)$ for TA100 and mitomycin $(3.0 \mu \mathrm{g} / \mathrm{plate})$ for TA102. In tests with metabolic activation, 2-antramine $(3.0 \mu \mathrm{g} /$ plate $)$ was used for all strains. DMSO $(75 \mu \mathrm{L} /$ plate $)$ served as the negative (solvent) control. All standards were purchase from Sigma Chemical Co.

The statistical analysis was performed with Salanal computer program, adopting the Bernstein et al., (1982) model. The mutagenic index (MI) was calculated for each dose, defined as the average number of revertants per plate divided by the average number of revertants per plate in the negative (solvent). A sample was considered positive when the mutagenic index was equal to or greater than 2 for at least one of the tested doses or if it had a reproducible dose-response curve
(Cardoso et al. 2006; Santos et al. 2010).

\section{Estrogenic and anti-estrogenic test}

\section{Cell line and culture conditions}

Cloned MCF-7 (human breast cancerBUS) cells were grown for routine maintenance in Dulbecco's modification of Eagle's medium (DMEM) supplemented with $10 \%$ FBS in an atmosphere of 5\% $\mathrm{CO}_{2}$ and $95 \%$ air under saturating humidity at $37{ }^{\circ} \mathrm{C}$. The cells were subcultivated at weekly intervals using a mixture of $0.05 \%$ trypsin and 0.01 EDTA (Sigma, St. Louis, MO, USA).

Charcoal-dextran treatment of serum to remove sex steroids

Sex steroids were removed from FBS by charcoal-dextran (CD) stripping. Briefly, a suspension of $5 \%$ charcoal (Sigma Chemical Co, St. Louis, MO, USA) with $0.5 \%$ dextran T-70 (Pharmacia-LKB, Uppsala, Sweden) was prepared. Aliquots of the CD suspension of a volume similar to the serum aliquot to be processed were centrifuged at $1000 \mathrm{x} g$ for 10 min. Supernatants were aspirated and serum aliquots were mixed with the charcoal pellets. This CD-serum mixture was maintained in suspension by rolling at 6 cycles/min at $37{ }^{\circ} \mathrm{C}$ for $1 \mathrm{~h}$. The suspension was centrifuged at $2000 \times \mathrm{g}$ for $20 \mathrm{~min}$, and the supernatant was then cultured through a $0.22 \mathrm{~mm}$ filter (Millipore). CD-treated FBS (CD-FBS) was stored at $-20{ }^{\circ} \mathrm{C}$ until needed.

\section{Cell proliferation experiments}

MCF-7 cells were used in the test of estrogenicity according to a technique slightly modified (Villalobos et al., 1995) from that originally described by Soto (Soto et al., 1992). Briefly, MCF-7 cells were trypsinized and plated in 24-well plates at initial concentrations of $1 \times 10^{4}$ cells per well in $10 \% \mathrm{FBS}$ in DMEM. Cells were allowed to attach for $24 \mathrm{~h}$; then, the seeding medium was removed and replaced by the experimental medium (10\% CD-FBS-supplemented phenol red-free DMEM).

A range of concentrations of the test compound was added to this medium into the sample wells. In each experiment, a dose-response curve (0.1 pM-1000 pM) of $\beta$-estradiol $\left(E_{2}\right)$, and a negative control (cell treated only with hormone-free medium) were included. The bioassay was terminated on day 6 (late exponential phase) by removing the media from the wells, fixing the cells and staining them with sulforhodamine B (SRB). The cells were treated with cold $10 \%$ trichloracetic 
acid and incubated at $4{ }^{\circ} \mathrm{C}$ for $30 \mathrm{~min}$, washed five times with tap water and left to try. Trichloroaceticfixed cells were stained for $10 \mathrm{~min}$ with $0.4 \%(\mathrm{w} / \mathrm{v})$ SRB dissolved in $1 \%$ acetic acid. Wells were rinsed with $1 \%$ acetic acid and air dried. Bound dye was solubilized with $10 \mathrm{mM}$ Tris base $(\mathrm{pH} 10.5)$ in a shaker for $20 \mathrm{~min}$. Finally, aliquots were transferred to a 96well plate and read in a Titertek Multiscan apparatus (Flow, Irvine, CA) at $492 \mathrm{~nm}$. Linearity of the SRB assay with cell number was verified prior to cell growth experiments. Mean cell numbers from each experiment were normalized to the hormone-free control cultures to correct for differences in the initial seeding density.

\section{Agonist and antagonist assays}

Estrogenic activity in MCF-7 cells was tested in the presence of increasing concentrations (0.001-10 $\mu \mathrm{M})$ of pristimerin and tingenone. Tests were performed in quadruplicate for each concentration. For each compound, the ratio between the cell yield obtained with the compounds tested and the proliferation of hormone-free control cells (negative control) was calculated. Results were expressed as proliferative effect (PE) [MCF-7 cell proliferation (fold-over control)]. Maximal MCF-7 cell proliferation was obtained in the presence of $100 \mathrm{pM} \mathrm{E}$. Antagonistic assays were performed using a concentration of agonist yielding approximately $85 \%$ of maximal cell proliferation. The antagonistic activities of these compounds (tested at 0.001-10 $\mu \mathrm{M}$ ) were determined by coincubation with the agonist $\mathrm{E}_{2}$ at $50 \mathrm{pM}$. Data were also expressed as PE for each compound tested.

For proliferation assays, each compound was tested at various concentrations in at least three independent experiments and data were expressed as mean \pm SD. Individual dose-response curves, in the absence and presence of agonist, were fitted using the sigmoid dose-response function of a graphics and statistics software package (Graph-Pad Prism, version 4.0, 2003, Graph-Pad Software Inc., San Diego, CA, USA). Results are presented as PE values. Data were analyzed for significant differences using one-way ANOVA followed by Dunnett's post-comparison test (vs. control). Differences were considered statistically significant when $p<0.05$.

\section{Results and Discussion}

This study evaluated the in vitro cytotoxicity of eight natural products such as tingenone, pristimerin, plumericine, cromene, scandenin, bauerenyl acetate, p-coumaric acid and chlorogenic acid. The compounds were evaluated in the cell lines of adenocarcinoma murine of the breast (LM3) and lung (LP07) and the results are showed in the Table 1 . The sequence for cytotoxic activity (including paclitaxel) observed in the LM3 line was: tingenone $>$ pristimerin $>$ plumericine $>$ cromene $>$ paclitaxel $>$ scandenin $>$ bauerenyl acetate $>$ $p$-coumaric acid $>$ chlorogenic acid. This sequence was similar to the LP07 cell line, the exception was the inverse order between chlorogenic and $p$-coumaric acid and between scandenin and paclitaxel.

Table 1. IC50 as average and standard deviation of each natural product assayed in the breast (LM3) and lung (LP07) tumor cell lines.

\begin{tabular}{lcc}
\hline \multirow{2}{*}{ Natural products } & \multicolumn{2}{c}{$\mathrm{IC50}(\mu \mathrm{M})$} \\
\cline { 2 - 3 } & $\mathrm{LM} 3$ & $\mathrm{LP} 07$ \\
\hline chromene & $63 \pm 10$ & $134 \pm 9$ \\
p-coumaric acid & $506 \pm 10$ & $3,075 \pm 275$ \\
chlorogenic acid & $942 \pm 119$ & $864 \pm 351$ \\
scandenin & $127 \pm 10$ & $152 \pm 13$ \\
plumericin & $32 \pm 10$ & $25 \pm 9$ \\
pristimerin (1) & $5 \pm 0$ & $5 \pm 0$ \\
tingenone (2) & $3 \pm 1$ & $2 \pm 1$ \\
bauerenyl acetate & $170 \pm 47$ & $852 \pm 192$ \\
paclitaxel & $74 \pm 0$ & $191 \pm 61$ \\
\hline
\end{tabular}

The quinona-methide triterpenes tingenone (IC50 $2 \mu \mathrm{M}$ in LP07 and $3 \mu \mathrm{M}$ in LM3) and pristimerin (IC50 $5 \mu \mathrm{M}$ in both LP07 and LM3) showed the largest level of cytotoxicity in the cell lines among the investigated compounds, even more active than the positive control adopted, paclitaxel (IC50 $74 \mu \mathrm{M}$ in LP07 and $191 \mu \mathrm{M}$ in LM3).

Pristimerin (1) and tingenone (2) belong to the class of quinona-methides triterpenes. They are secondary metabolites isolated exclusively from barks and roots of plants from Celastraceae and Hippocrateaceae, and are considered chemotaxonomic markers to these families (Alvarenga at al., 1999).
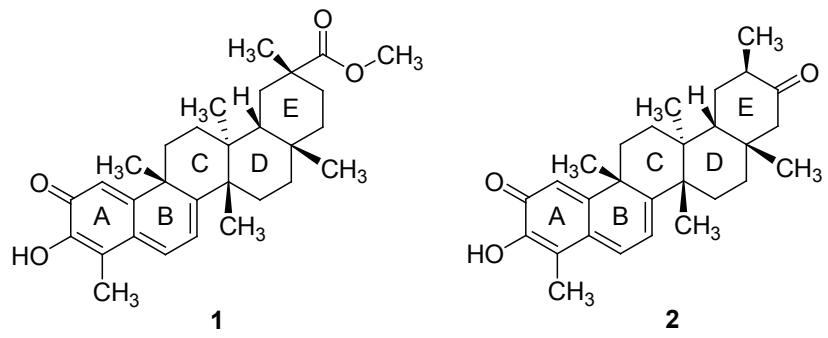

Pristimerin (1) and tingenone (2) have demonstrated potent in vitro biological activities; most of them associated with their cytotoxic activity (Klaid et al., 2007; Tahir et al., 2001; Mena-Rejo et al., 2007; Pavanad et al., 1989), especially in several cancer cell lines (Costa et al., 2008). Other publications also reveal 
that pristimerin has anti-inflammatory action in animal models (Hui et al., 2003), while tingenone, even at low concentrations, exerted a marked inhibitory effect on protein and RNA synthesis (Angeleti \& Marini-Betollo, 1974).

It is known that pristimerin exhibits cytotoxicity in several cancer cell lines (Costa et al., 2008), but the mechanism involved in the cytotoxic effect of pristimerin has not been completely explored. $\mathrm{Wu}$ et al. (2005) observed that human breast cancer cells (MDA/MB-231) treated with pristimerin induced the release of cytochrome $c$ from mitochondria and a decreasing of the mitochondrial potential, leading to a caspase-dependent apoptosis. The same authors also reported that pristimerin may have potential selectivity toward tumor cells.

Costa et al. (2008) reported that pristimerin inhibited DNA synthesis and triggered cell death apparently by apoptosis, however, it was not able to inhibit human topoisomerase I. Yang et al. (2008) verified that pristimerin induces death of human prostate cancer cells (PC-3 and C4-2B) due its potent proteasome inhibition, and also by interaction with caspase, leading to apoptosis.

Liby et al. (2007) described the importance of carbonyl $\alpha, \beta$-unsaturated groups to anti-inflammatory and antitumoral action of triterpenoids as 28-(2-cyan)3,12-dioxooleanan-1,9(11)-dienoic acid (CCDO), an oleanoic acid derivative. The suggested mechanism of action involved the nucleophilic attack of CCDO to protein sulfidryl groups from cisteyne residues through Michael's reaction.

Yang et al. (2008) evaluated the nucleophilic susceptibility of pristimetin by Quantum CAChe program. Results showed high susceptibility to nucleophilic attack in $\mathrm{C}_{2}$ and $\mathrm{C}_{6}$. These regions are interaction points between the triterpenes and hydroxyl groups from $N$ - terminal portion of $\beta 5$ proteasome subunit threonine amino acid.

Acurate evaluation of the structures using the ACD/Chem Sketch 4.0 program evidenced that positions $\mathrm{C} 2$ and $\mathrm{C} 6$ of pristimerin are less hindered that those in $\mathrm{CCDO}$, due the planar orientation of the $\mathrm{A}$ and $\mathrm{B}$ rings, which might result in a higher nucleophilic susceptibility than CCDO.

Michael's reaction is reversible, what makes difficult to isolate and identify the complex formed. Liby et al. (2007) described that the treatment of tumor cells in vitro with CCDO in presence of thiol-containing reagents as $\mathrm{N}$-acetylcisteyne promoted a decreasing in the CCDO cytotoxicity, thus suggesting the interaction between CCDO and sulfidryl groups (Scheme 1).

The interaction between pristimerin and tingenone with $\mathrm{N}$-acetylcisteyne was also evaluated by spectrophotometric analysis (Table 2). The hypochromic effect after $30 \mathrm{~min}$ of reaction for both pristimerin and tingenone reinforced the interaction between these triterpenes and sulfidryl groups.

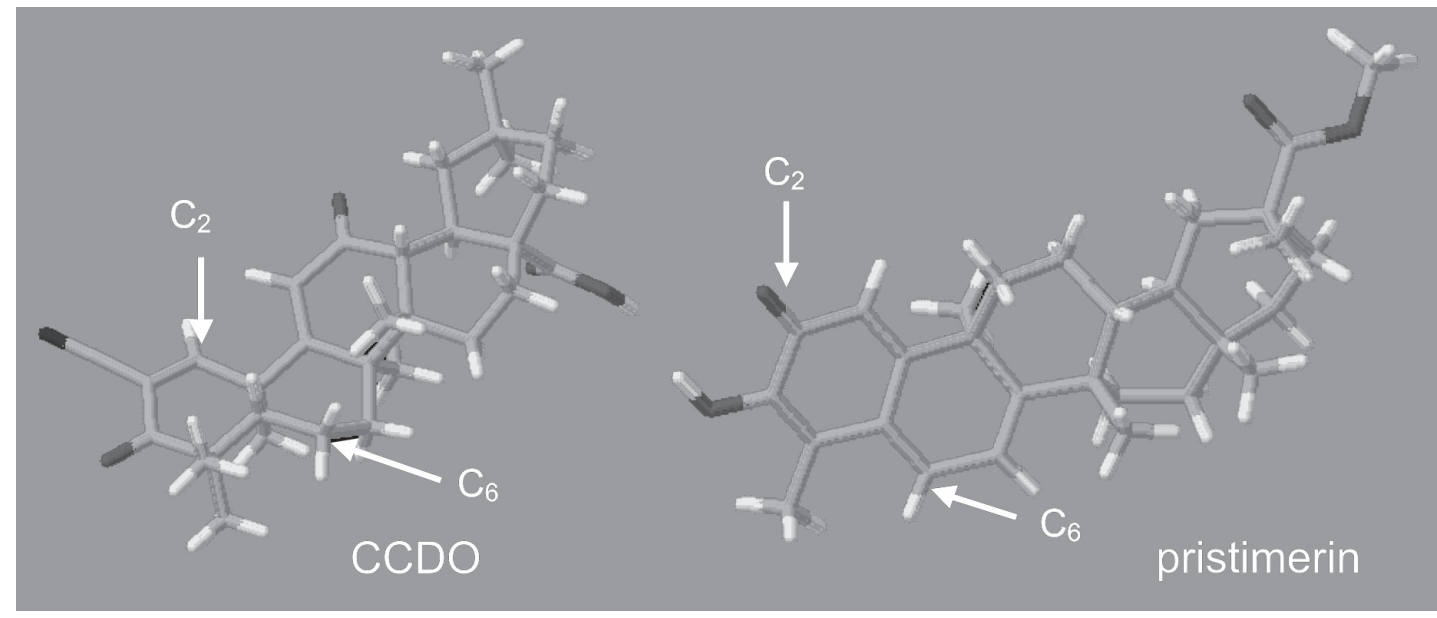

Figure 1. Pristimerin (1) and CCDO tridimensional chemical structures.
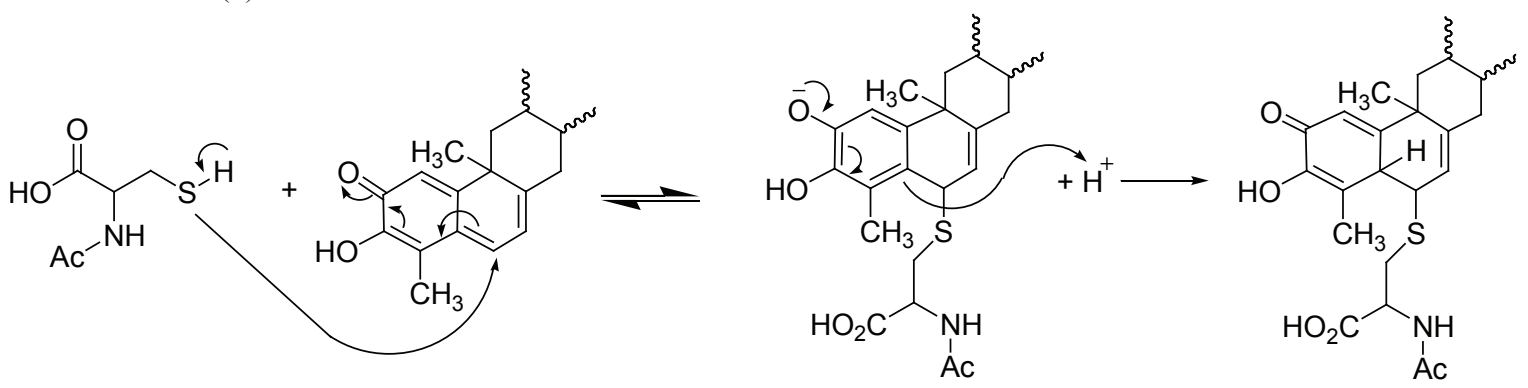

Scheme 1. Representation of Michael's reaction between $\mathrm{N}$-acetylcisteyne and $\mathrm{C}_{6}$ from pristimerin or tingenone. 
Therefore, we tested tumor cell lines LM3 and LP07 treated with pristimerin and tingenone in presence of $\mathrm{N}$-acetylcisteyne. The results evidenced a significative increase of the IC50 values for both substances in both cell lines, and thus a decrease in the cytotoxicity of these triterpenes (Table 2).

Table 2. IC50 and spectrophotometrical analysis of pristimerin and tingenone with and without $N$-acetylcisteyne.

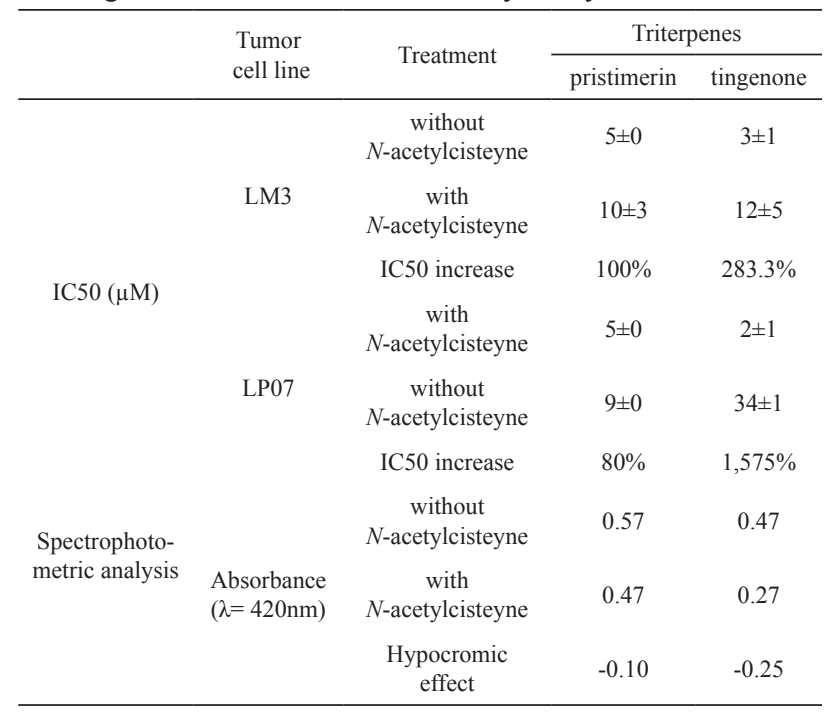

The interaction between tingenone and DNA was appointed as one likely mechanism for its cytotoxicity (Godjiman et al., 1985) and antineoplastic activities (Campanelli et al., 1980). This interaction was noticed by spectral methods, but no evidence could be concerning about a relationship between the binding mode and the base composition. The size and shape of tingenone molecule are favorable for its inclusion in the narrow groove of DNA and, furthermore, hydrogen bonds can be formed between the hydroxyl group of tingenone and the phosphate group of DNA. Since tingenone is a bulky molecule, an intercalation mechanism seems to be unlikely, unless only the nearly planar A and B rings are engaged. The same mechanism could be applicable for pristimerin, since the only modification is on E ring.

The mutagenicity results reinforce the hypothesis where resulting effects of the intercalation of the pristimerin and tingenone in DNA were not observed. The strains TA98 and TA97a detect frameshift mutations that are usually induced by intercalating agents in DNA.

The mutagenic activity data obtained in the Salmonella/microsome assays for pristimerin and tingenone are shown in Table 3. Pristimerin and tingenone did not show mutagenic activity, evaluated by the Ames test that detects point mutations with and without metabolic activation (S9).

Morita et al. (2008) reported the antimitotic activity of pristimerin and tingenone. Antimitotic agents that inhibit the microtubule formation and the mitotic arrest of eukaryotic cells, such as paclitaxel and vinblastine, are important components on current anticancer therapy and have potential applications in drug development. Recently much effort has been directed to the isolation and synthesis of the antimitotic drugs that target the tubulin/microtubule system and display efficacy against drug-refractory carcinomas.

In the present work, we also studied the effects of pristimerin and tingenone on cell proliferation for evaluation of the estrogenic activity of these compounds. The MCF-7 proliferation assay (e-screen) which is based on proliferation of human mammary adenocarcinoma cells ER $\alpha$ (estrogen receptor $\alpha$ ) positive, is a well accepted method for evaluation of estrogenic effects initiated by phytochemicals (Mesa-Siverio et al., 2008; Cherdshewasart et al., 2008). This system has also been used in evaluating the anti-estrogenic activity of chemicals (Silva et al., 2006; Nielsen \& Rasmussen, 2004). Cells were incubated for $144 \mathrm{~h}$ at $37{ }^{\circ} \mathrm{C}$ in the presence of E2 at the indicated concentrations (Figure 2). Results are expressed as proliferative effect (ratio between the highest cell yield obtained with the chemical and the proliferation of hormone-free control cells). Values were the mean $\pm \mathrm{SD}$ from three separate experiments. As expected, in this cell line E2 strongly induced significant proliferation in a clear dose-dependent manner (Figure 2). By contrast, pristimerin and tingenone did not stimulate MCF-7 cell proliferation in the concentration range of $0.001-10 \mu \mathrm{M}$ (Table 4), indicating that these compounds are not estrogenic. At the highest tested concentration $(10 \mu \mathrm{M})$, cytotoxic events occurred with pristimerin and tingenone, explaining the lack of cell proliferation for this concentration.

\section{Estradiol $\left(\mathrm{E}_{2}\right)$}

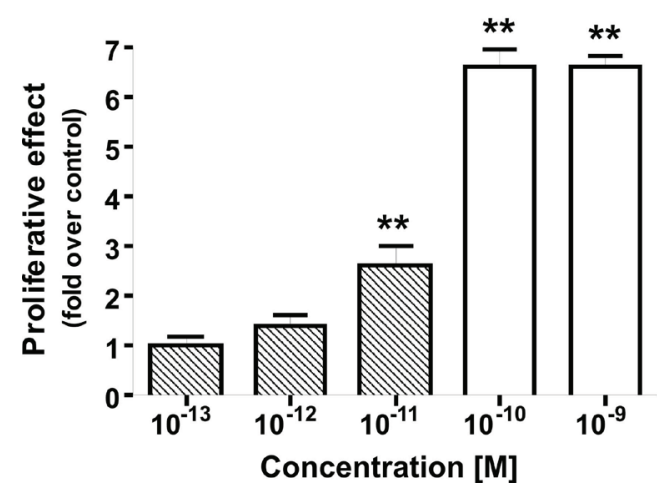

Figure 2: Dose-proliferative response curve for $\mathrm{E}_{2}$ in MCF-7 cells. ${ }^{* *} p<0.01$ (versus hormone-free control).

Prompted by reports on the strong antiproliferative activity of pristimerin in several cell lines (Wu et al., 2005), we also examined the potential anti-estrogenic activity of these compounds using 
Table 3. Mutagenic activity expressed as the mean and standard derivation of the number of revertants/plate in bacterial Salmonella typhimurium strains TA98, TA97a, TA100 and TA102 treated with pristimerin and tingenone at various doses, with $(+$ S9) and without (-S9) metabolic activation.

\begin{tabular}{|c|c|c|c|c|c|c|c|c|}
\hline \multirow{3}{*}{$\begin{array}{l}\text { Treatment } \\
(\mu \mathrm{M} / \text { plate })\end{array}$} & \multicolumn{8}{|c|}{ Revertants colonies/plate in S. typhimurium strains } \\
\hline & \multirow{2}{*}{$\begin{array}{c}\text { TA98 } \\
\text {-S9 }\end{array}$} & \multirow{2}{*}{$+\mathrm{S} 9$} & \multirow{2}{*}{$\begin{array}{c}\text { TA97a } \\
\text {-S9 } \\
\end{array}$} & \multirow{2}{*}{ +S9 } & \multirow{2}{*}{$-\mathrm{S} 9$} & \multirow{2}{*}{$\begin{array}{l}\text { TA100 } \\
+ \text { S9 }\end{array}$} & \multicolumn{2}{|c|}{ TA102 } \\
\hline & & & & & & & $-\mathrm{S} 9$ & $+\mathrm{S} 9$ \\
\hline \multicolumn{9}{|l|}{ Pristimerin } \\
\hline $0.000^{\mathrm{a}}$ & $67 \pm 3$ & $29 \pm 7$ & $168 \pm 31$ & $199 \pm 32$ & $131 \pm 21$ & $127 \pm 8$ & $371 \pm 12$ & $291 \pm 18$ \\
\hline 0.010 & $66 \pm 9(1.0)$ & $33 \pm 6(1.1)$ & $202 \pm 29(1.2)$ & $201 \pm 28(1.0)$ & $157 \pm 9(1.2)$ & $121 \pm 8(1.0)$ & $382 \pm 11(1.0)$ & $240 \pm 34(0.9)$ \\
\hline 0.020 & $62 \pm 3(0.9)$ & $36 \pm 4(1.2)$ & $168 \pm 9(1.0)$ & $204 \pm 17(1.0)$ & $126 \pm 9(1.0)$ & $108 \pm 8(0.9)$ & $368 \pm 32(1.0)$ & $277 \pm 27(1.0)$ \\
\hline 0.040 & $70 \pm 9(1.0)$ & $42 \pm 8(1.4)$ & $178 \pm 14(1.1)$ & $186 \pm 17(0.9)$ & $124 \pm 16(1.0)$ & $148 \pm 41(1.2)$ & $399 \pm 38(1.0)$ & $271 \pm 46(0.9)$ \\
\hline 0.080 & $71 \pm 4(1.1)$ & $33 \pm 6(1.1)$ & $162 \pm 5(1.0)$ & $175 \pm 13(0.9)$ & $114 \pm 21(0.9)$ & $117 \pm 22(0.9)$ & $321 \pm 9(1.0)$ & $306 \pm 27(1.0)$ \\
\hline 0.120 & $58 \pm 6(0.9)$ & $28 \pm 8(0.9)$ & $161 \pm 14(1.0)$ & $181 \pm 16(0.9)$ & $110 \pm 9(0.8)$ & $101 \pm 18(0.8)$ & $383 \pm 22(1.0)$ & $313 \pm 22(1.0)$ \\
\hline \multicolumn{9}{|l|}{ Tingenone } \\
\hline $0.000 \mathrm{a}$ & $67 \pm 3$ & $29 \pm 7$ & $168 \pm 31$ & $199 \pm 32$ & $131 \pm 21$ & $127 \pm 8$ & $371 \pm 12$ & $291 \pm 18$ \\
\hline 0.003 & $60 \pm 1(0.9)$ & $32 \pm 11(1.1)$ & $188 \pm 14(1.1)$ & $192 \pm 4(1.0)$ & $136 \pm 6(1.0)$ & $116 \pm 8(0.8)$ & $371 \pm 31(1.0)$ & $237 \pm 10(0.8)$ \\
\hline 0.006 & $59 \pm 11(0.9)$ & $28 \pm 4(1.0)$ & $177 \pm 15(1.0)$ & $204 \pm 17(1.1)$ & $153 \pm 10(1.1)$ & $117 \pm 8(0.9)$ & $345 \pm 11(0.9)$ & $262 \pm 27(0.9)$ \\
\hline 0.012 & $54 \pm 1(0.8)$ & $38 \pm 2(1.3)$ & $131 \pm 23(0.8)$ & $170 \pm 34(0.9)$ & $131 \pm 9(1.0)$ & $111 \pm 7(0.9)$ & $285 \pm 21(0.8)$ & $276 \pm 36(0.9)$ \\
\hline 0.024 & $62 \pm 11(0.9)$ & $31 \pm 7(1.1)$ & $86 \pm 14(0.5)$ & $151 \pm 6(0.8)$ & $122 \pm 5(0.9)$ & $138 \pm 36(1.1)$ & $147 \pm 12(0.4)$ & $269 \pm 36(0.9)$ \\
\hline 0.031 & $69 \pm 2(1.0)$ & $34 \pm 2(1.1)$ & $79 \pm 10(0.5)$ & $180 \pm 12(0.9)$ & $117 \pm 11(0.9)$ & $111 \pm 4(0.9)$ & $130 \pm 27(0.4)$ & $307 \pm 7(1.0)$ \\
\hline 0.008 & $37 \pm 3(1.2)$ & $26 \pm 8(0.9)$ & $211 \pm 3(1.3)$ & $274 \pm 24(1.4)$ & $161 \pm 30(1.2)$ & $141 \pm 43(1.1)$ & $376 \pm 12(1.2)$ & $295 \pm 35(1.0)$ \\
\hline 0.014 & $32 \pm 4(1.0$ & $35 \pm 2(1.2)$ & $209 \pm 29(1.2)$ & $260 \pm 7(1.3)$ & $112 \pm 3(0.8)$ & $108 \pm 10(0.9)$ & $365 \pm 28(1.2)$ & $305 \pm 17(1.0)$ \\
\hline Control $+\mathrm{b}$ & $1480 \pm 243$ & $2222 \pm 78$ & $1617 \pm 450$ & $1250 \pm 269$ & $992 \pm 249$ & $1638 \pm 547$ & $1737 \pm 92$ & $1354 \pm 41$ \\
\hline
\end{tabular}

${ }^{a}$ negative control (DMSO, $75 \mu \mathrm{L} /$ plate). b positive control: sodium azide $(2.5 \mu \mathrm{g} /$ plate,TA100), mitomycin (3.0 $\mu \mathrm{g} / \mathrm{plate}, \mathrm{TA} 102)$ and 4-nitro- $O$ phenylenediamine $(10 \mu \mathrm{g}$ /plate,TA98,TA97a) without S9; and 2-antramine $(3.0 \mu \mathrm{g} /$ plate,TA98, TA97a, TA100, TA102) with S9. The values in parenthesis $=$ mutagenic index. No statistical differences were observed.

the estrogen-sensitive MCF-7 cells. Pristimerin and tingenone failed to antagonize E2-induced proliferation (Figure 3). Consistent with the data obtained in proliferation assays, the two compounds caused cell toxicity at the highest tested concentration.

Table 4. MCF-7 cell proliferation. Cells were incubated for $144 \mathrm{~h}$ at $37^{\circ} \mathrm{C}$ in the presence of pristimerin and tingenone at the indicated concentrations.

\begin{tabular}{lcc}
\hline Compounds & PE (Fold-over control) & P (vs. control) \\
\hline $\mathrm{E}_{2}\left(10^{-10} \mathrm{M}\right)$ & $6.50 \pm 0.20$ & $<0.01$ \\
Pristimerin $\left(10^{-9} \mathrm{M}\right)$ & $1.07 \pm 0.04$ & $>0.05$ \\
Pristimerin $\left(10^{-8} \mathrm{M}\right)$ & $1.06 \pm 0.05$ & $>0.05$ \\
Pristimerin $\left(10^{-7} \mathrm{M}\right)$ & $1.11 \pm 0.01$ & $>0.05$ \\
Pristimerin $\left(10^{-6} \mathrm{M}\right)$ & $1.06 \pm 0.07$ & $>0.05$ \\
Pristimerin $\left(10^{-5} \mathrm{M}\right)$ & $0.15 \pm 0.15^{*}$ & $<0.01$ \\
Tingenone $\left(10^{-9} \mathrm{M}\right)$ & $1.03 \pm 0.04$ & $>0.05$ \\
Tingenone $\left(10^{-8} \mathrm{M}\right)$ & $1.04 \pm 0.09$ & $>0.05$ \\
Tingenone $\left(10^{-7} \mathrm{M}\right)$ & $1.10 \pm 0.02$ & $>0.05$ \\
Tingenone $\left(10^{-6} \mathrm{M}\right)$ & $1.10 \pm 0.01$ & $>0.05$ \\
Tingenone $\left(10^{-5} \mathrm{M}\right)$ & $0.10 \pm 0.04^{*}$ & $<0.01$ \\
\hline
\end{tabular}

Results are expressed as PE: proliferative effect (ratio between the highest cell yield obtained with the chemical and the proliferation of hormone-free control cells). Values were the mean $\pm \mathrm{SD}$ from three separate experiments. $p<0.05$ and $p<0.01$ (versus hormone-free control). *Cell toxicity.
In conclusion the quinona-methide triterpenes tingenone (2) and pristimerin (1) showed the highest cytotoxicity in the LP7 and LM3 cell lines. The structureactivity relationship suggests that rings $\mathrm{A}$ and $\mathrm{B}$ containing an $\alpha$-, $\beta$-unsaturated carbonyl group are essential for the observed cytotoxic activity. The interaction between pristimerin and tingenone with $N$-acetylcisteyne was evaluated by biological and spectrophotometric methods. These results and literature data taken together reinforce the evidence that pristimerin and tingenone may induce apoptosis by interaction to caspases, an important family of proteins with cisteyne residues.

The in vitro mutagenic activity was evaluated for the most promising compounds: pristimerin and tingenone and they did not show mutagenic potential. Finally, (anti)estrogenic activity of pristimerin and tingenone were analyzed in vitro by measuring the proliferation of estrogen-sensitive $\mathrm{MCF}-7$ cells. In contrast to $\mathrm{E}_{2}$, included as positive control, these compounds failed to induce cell proliferation in this cell line at concentrations between 0.001 and $10 \mu \mathrm{M}$. Pristimerin and tingenone also failed to act as an antiestrogen, but the two compounds caused cell toxicity at the highest tested concentration.

Therefore, these molecules seem to be lead compounds for new anticancer drugs. 
Tingenone

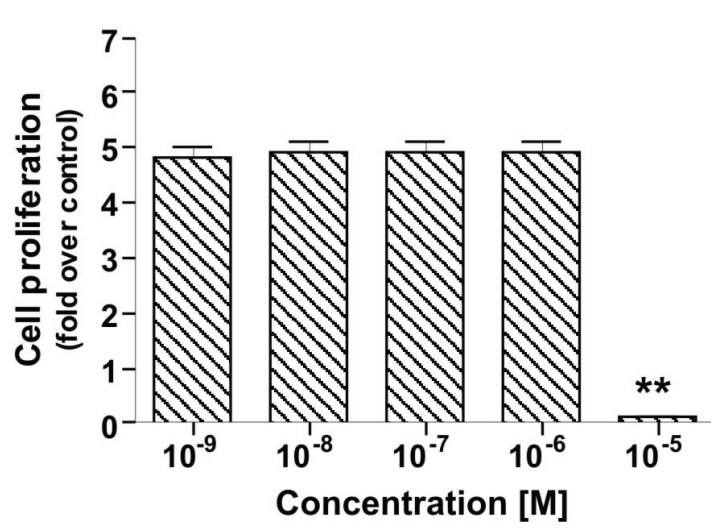

Pristimerin

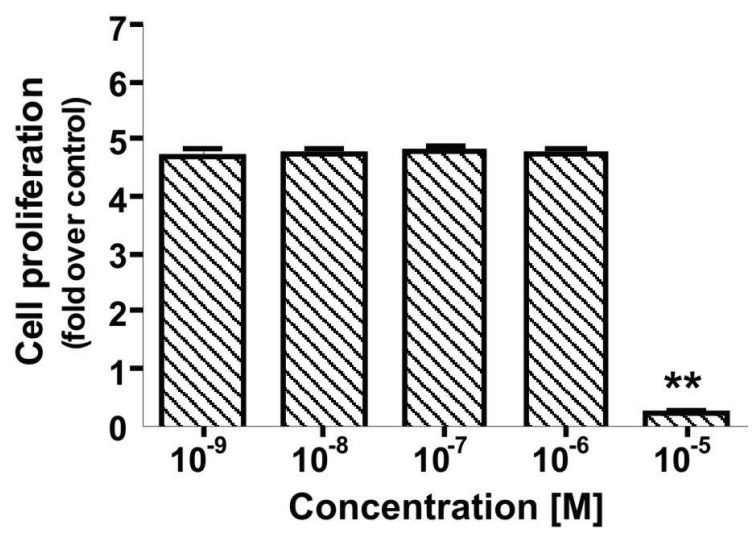

Figure 3. Inhibition of cell proliferation in MCF-7 cells. MCF-7 cells were treated with $50 \mathrm{pM} \mathrm{E}_{2}$ in the presence of increasing concentrations of pristimerin and tingenone for $144 \mathrm{~h}$. Results are expressed as proliferative effect (ratio between the highest cell yield obtained with the chemical and the proliferation of hormone-free control cells). Values were the mean $\pm \mathrm{SD}$ from three separate experiments. ${ }^{*}$ Cell toxicity.

\section{Acknowledgment}

The authors thank the Conselho Nacional de Desenvolvimento Científico e Tecnológico for financial support to Gomes JPM, Vilegas W, Varanda EA, Carlos IZ; Dr. B. Ames, University of California (Berkeley, CA, USA) by kindly provides the $S$. typhimurium strains; Prof. Dr. Lucas L. Colombo (Angel H. Roffo Oncology Institute, Buenos Aires, Argentina) by provides the tumoral cell lines LM3 and LP07 and Cecilia Holmes for the English review.

\section{Reference}

Alvarenga NL, Velásquez CA, Canela NJ, Bazzochi LL, Ferm EA 1999. A new antibiotic nortiterpene quinone methide from Maytenus catingarum. J Nat Products 62: 750751.

Angeleti PU, Marini-Betollo GB 1974. Effect of maitenine on RNA and protein shyntesis in cell cultures. Farmaco 28: 569-585.

Bernstein L, Kaldor J, McCann J, Pike MC 1982. An empirical approach to the statistical analysis of mutagenesis data from the Salmonella test. Mutat Res 97: 267-281.

Brinker AM, Ma J , Lipsky PE, Raskin I 2007. Medicinal chemistry and pharmacology of genus Tripterygium (Celastraceae). Phytochemistry 68: 732-766.

Campanelli AR, Dálagni M, Bettolo GBM 1980. Spectroscopic evidence for the interaction of tingenone with DNA. FEBS Lett 122: 256-260.

Cardoso CRP, Cólus IMS, Bernardi CC, Sannomya M, Vilegas W, Varanda EA 2006. Evaluation of the mutagenic activity promoted by amentoflavone and methanolic extract of Byrsonima crassa Niedenzu. Toxicology 225: 55-63.

Cherdshewasart W, Traisup V, Picha P 2008. Determination of the estrogenic activity of wild phytoestrogen-rich Pueraria mirifica by MCF-7 proliferation assay. J Reprod Develop 54: 63-67.

Costa PM, Ferreira PMP, Bolzani VS, Furlan M., Santos VAFFM, Corsino J 2008. Antiproliferative activity of pristimerin isolated from Maytenus ilicifolia (Celastracea) in human HL-60 cells. Toxicol in vitro 22: 854-863.

Dimitrakakis C, Gosselink L, Gaki V, Bredakis N, Keramopoulos A 2004. Phytoestrogen supplementation: a case report of male breast cancer. Eur J Cancer Prev 13:481-484.

Gao JM, Wu WJ, Zhang JW, Konishi Y 2007. The dihydro-betaagarofuran sesquiterpenoids. Nat Prod Rep 24: 11531189.

Godjiman SG, Turrens JF, Marini-Bettolo GB, Stoppani AOM 1985. Effect of tingenone, a quinone triterpene, on growth and macromolecule biosynthesis in Trypanossoma cruzi. Experientia 41: 646-648.

Hui B, Wu Y, Wang H, Tian X 2003. Effect of pristimerin on experimental inflammation in mice and rats. Chin Pharma Bull 19: 656-659.

Klaid SA, Friedrichsen GEM, Christensen SB, El Tahir A, Satti OM 2007. Isolation and characterization of pristimerine as the antiplasmodial and antileishmanial agent of Maytenus senegasis (Lam.) Excell. Akta USA Inc 9: 129134.

Liby KT, Yore MM, Sporn MB 2007. Triterpenoids and rexinoids as multifunctional agents for the prevention and treatment of cancer. Nat Rev Cancer 7: 357-369.

Lynch N, Berry D 2007. Differences in perceived risks and benefits of herbal, over-the-counter conventional, and prescribed conventional, medicines, and the implications of this for the safe and effective use of herbal products. Complement Ther Med 15: 84-91.

Maron DM, Ames BN 1983. Revised methods for the Salmonella mutagenicity test. Mutat Res 113: 173-215.

Mena-Rejo GJM, Espadas ARP, Pue REM, Riviera RC, Bazzoci LL, Diaz IAJ 2007. Antigiardial activity of triterpenoids from root bark of Hippocratea excelsa. J Nat Prod 70: 
863-865.

Mesa-Silverio D, Machín RP, Estevez-Braun A, Ravelo AG, Lock O 2008. Structure and estrogenic activity of new lignans from Iryanthera lancifolia. Bioorgan Med Chem 16: 3387-3394.

Messina MJ, Wood CE 2008. Soy isoflavones, estrogen therapy, and breast cancer risk: analysis and commentary. Nutr $J$ 7: 17-19.

Morita H, Hirasawa Y, Muto A, Yoshida T, Sekita S, Shirota O 2008. Antimitotic quinoid triterpenes from Maytenus chuchuhuasca. Bioorg Med Chem Lett 18: 1050-1052.

Mortelmans K, Zeiger E 2000. The Ames Salmonella/Microsome mutagenicity assay. Mutat Res 455: 29-60.

Mosmamm T 1983. Rapid colorimetric assay for cellular grown and survival: application to proliferation and cytotoxicity assays. J Immunol Methods 65: 55-63.

Nielsen JB, Rasmussen TH 2004. Antiproliferative effect of butyltin in MCF-7 cells. Environ Res 96: 305-310.

Pavanak K, Webster H K, Yongvanitchit K, Kun-Anake A, Dechatiwongse T, Nutakul W 1989. Schinzontocidal activity of Celastrus paniculatus wild against Plasmodium falciparum in vitro. Phytother Res 3:136139

Roberts H 2010. Safety of herbal medicinal products in women with breast cancer. Maturitas 66(4): 363-369.

Salminen M, Lehtone T, Suuronen K, Kaarniranta J, Huuskonen J 2008. Terpenoids: natural inhibitors of NF-kB signaling with anti-inflammatory and anticancer potential. Cell Mol Life Sci 65: 2979-2999.

Santos FV, Calvo TR, Colus IMS, Vilegas W, Varanda EA 2010. Mutagenicity of two species of the genus Alchornea measured by Salmonella microsome assay and micronucleus test. Rev Braz Farmacogn 20: 382-389.

Silva E, Lopez-Espinosa MJ, Molina-Molina JM, Fernández M, Olea N, Kortenkamp A 2006. Lack of activity of cadmium in vitro estrogenicity assays. Toxicol Appl Pharm 216: 20-28.

Soto AM, Lin TM, Justicia H, Silvia RM, Sonnenschein C 1992. An in culture bioassay to assess the estrogenicity of xenobiotics. In: Chemically Induced alterations in sexual development: the wildlife/human connection. Colborn T., Clement C. R. ed. Princeton, NJ: Princeton Scientific Publishing.

Soto AM, Sonnenschein C, Chung KL, Fernandez MF, Olea N, Serrano FO 1995. The e-screen assay as a tool to identify estrogens: an update on estrogenic environmental pollutants. Environ Health Persp 103:113-122.

Spink BC, Cole RW, Katz BH, Gierthy JF, Bradley LM, Spink DC 2006. Inhibition of MCF-7 breast cancer cell proliferation by MCF-10A breast epithelial cells in coculture. Cell Biol Int 30: 227-138.

Tahir AE, Satti GMH, Sami A 2001. A novel antiplasmodial activity of pristimerin isolated from Maytenus senegalasis (Lam.). J Saudi Chem Soc 5: 157-163.

Villalobos M, Olea N, Brotons JA, Olea-Serrano MF, Ruiz de Almodóvar JM, Pedraza V 1995. E-screen assay: a comparison of different MCF7 cell stocks. Environ Health Persp 103: 844-850.

Wu C, Chan M, Chen W, Tsai C, Chang F, Wu Y 2005. Pristimerin induces caspase-dependent apoptosis in MDA-MB-231 cells via direct effects on mitochondria. Mol Cancer Ther 4: 1277-1785.

Xin D, Wang H, Yang J, Su YF, Fan GW, Wang YF, Zhu Y, Gao XM 2009. Phytoestrogens from Psoralea corylifolia reveal estrogen receptor-subtype selectivity. Phytoma 17: 126-131.

Yang H, Landis-Piwowar KR, Lu D, Li L, Redd GP, Dou QP 2008. Pristimerin induces apoptosis by targeting the proteossoma in prostate cancer cells. J Cell Biochem 103: 234-244.

\section{*Correspondence}

Eliana A. Varanda

Faculdade de Ciências Farmacêuticas, Universidade Estadual Paulista "Júlio de Mesquita Filho, Campus Araraquara, Brazil varandae@fcfar.unesp.br

Tel. +551633016951, 33016940 